\title{
Plasma microbial cell-free DNA load is associated with mortality in patients with COVID-19
}

\author{
Georgios D. Kitsios ${ }^{1 *}$ D, William Bain ${ }^{1,2}$, Nameer Al-Yousif ${ }^{3}$, Radha Duttagupta ${ }^{4}$, Asim A. Ahmed ${ }^{4}$, \\ Bryan J. McVerry and Alison Morris ${ }^{1}$
}

\section{Introduction}

Severe COVID-19 pneumonia requiring intensive care unit (ICU) support can be complicated by secondary bacterial or fungal infections. The incidence and impact of secondary pneumonias in COVID-19 are not welldefined because clinical distinction from isolated SARS$\mathrm{CoV}-2$ infection is challenging and diagnostic practices have been highly variable [1]. Early administration of empiric antibiotics limits the sensitivity of subsequent microbiologic studies, whereas standard invasive workup with bronchoscopy is often avoided due to the risks of healthcare personnel exposure to aerosolized SARSCoV-2 [2]. To overcome such limitations and comprehensively identify secondary pneumonias in COVID-19, we performed microbial cell-free DNA (mcfDNA) metagenomic sequencing (mcfDNA-Seq) in plasma samples in addition to conventional microbiologic workup.

\section{Methods}

We enrolled 15 critically-ill patients with COVID-19 (confirmed by nasopharyngeal qPCR for SARS-CoV-2) in a prospective ICU cohort study [3]. Following informed consent, we obtained plasma samples for conducting mcfDNA-Seq with the Karius Test (Karius, Inc. Redwood City, CA)[4]. We evaluated detection of mcfDNA in the

\footnotetext{
*Correspondence: kitsiosg@upmc.edu

${ }^{1}$ Division of Pulmonary, Allergy and Critical Care Medicine, Acute Lung Injury Center of Excellence, University of Pittsburgh Medical Center, UPMC Montefiore Hospital, NW 628, 3459 Fifth Avenue, Pittsburgh, PA 15213, USA

Full list of author information is available at the end of the article
}

context of clinical diagnoses and prescribed antimicrobial therapies by the treating physicians, and examined for associations with clinical outcomes.

\section{Results}

Of 15 patients analyzed (median age 63, 53\% females, $73 \%$ mechanically-ventilated), six (40\%) died within 30 days from enrollment. Samples were obtained at a median (interquartile range-IQR) of 10 (4-12) days from COVID-19 symptoms onset, and each sample contained a median of $837(111-4638)$ total mcfDNA molecules per microliter (MPMs) and 2 (1-4) identified organisms. Of the total 92,791 MPMs reported across 15 samples, 90\% belonged to typical pathogenic bacteria (e.g. E.coli and $K$. Pneumoniae), with the remainder MPMs aligned to commensal bacteria (5\%, e.g. oral Streptococcus species), fungi (4\%, Candida species) and DNA viruses (1\%). Compared to survivors, non-survivors had higher total mcfDNA $(p=0.04)$, higher pathogenic bacteria MPMs $(p=0.02)$ and a trend for a higher number of identified organisms per sample $(\mathrm{p}=0.06)$. (Fig. 1$)$.

Secondary pneumonia was clinically suspected or diagnosed by the treating physicians in 11/15 (73\%) patients (Group A, Fig. 2), with microbiologic confirmation by positive respiratory cultures in $3 / 11$ subjects (27\%); these three patients had high plasma mcfDNA MPMs for common bacterial pathogens, such as E.coli and Ps. aeruginosa. Among the remaining eight patients with clinically-suspected infections and empiric antibiotic treatments, high mcfDNA MPMs of probable bacterial pathogens were detected in $2 / 8$ patients (co-infecting original author(s) and the source, provide a link to the Creative Commons licence, and indicate if changes were made. The images or other third party material in this article are included in the article's Creative Commons licence, unless indicated otherwise in a credit line to the material. If material is not included in the article's Creative Commons licence and your intended use is not permitted by statutory regulation or exceeds the permitted use, you will need to obtain permission directly from the copyright holder. To view a copy of this licence, visit http://creativecommons.org/licenses/by/4.0/. The Creative Commons Public Domain Dedication waiver (http://creativeco mmons.org/publicdomain/zero/1.0/) applies to the data made available in this article, unless otherwise stated in a credit line to the data. 

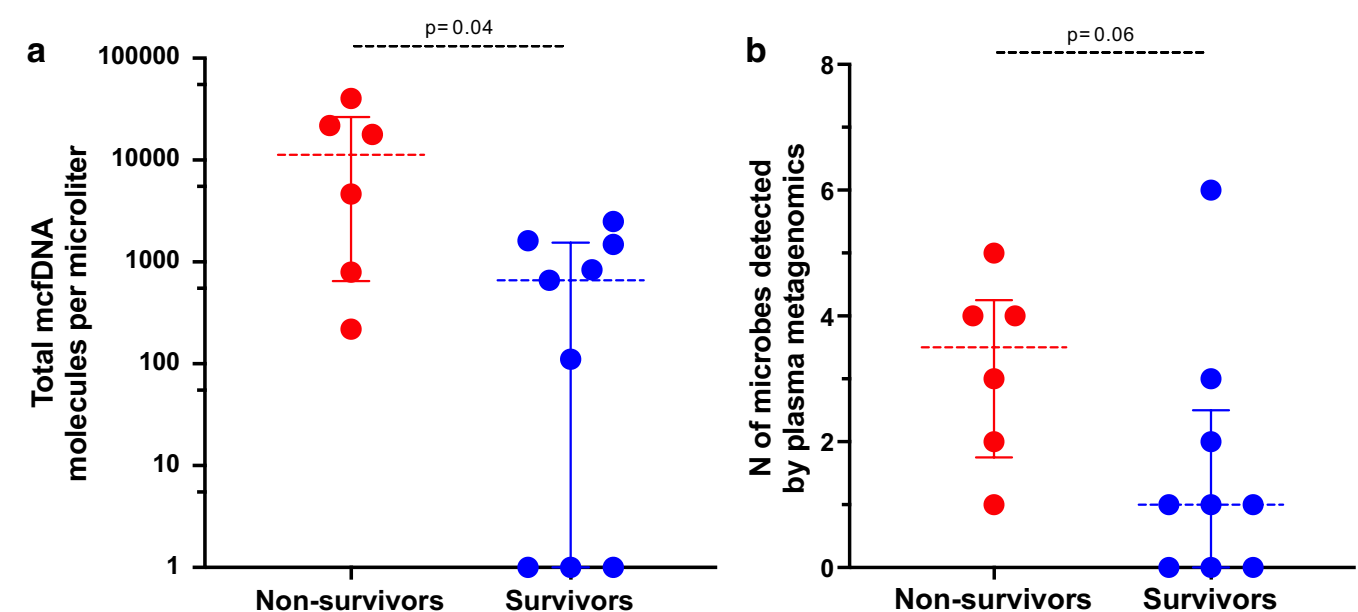

Fig. 1 Non-survivors of severe COVID-19 infection had higher microbial cell-free DNA molecules per microliter of plasma by metagenomic sequencing compared to survivors (median [interquartile range]: 11,125 [650-26,436] vs. 661 [1], Wilcoxon test p-value $=0.04$ ) and a trend for higher number of identified microbes per sample (3.5 [1.8-4.3] vs. $1.0[0-2.5]$, Wilcoxon test p-value $=0.06)$

Ps. aeruginosa and K. Pneumoniae; Raoultella ornithinolytica, respectively). In the additional six patients, no evidence of co-infecting bacterial pathogens was present, whereas in one patient (subject 7, Fig. 2) there was high signal for Candida tropicalis (2,490 MPMs) concerning for undiagnosed invasive Candidiasis.

We detected respiratory pathogen MPMs (S. aureus, Ps. aeruginosa and K. Pneumoniae) in $3 / 4$ subjects with low suspicion for secondary infection (Group B, Fig. 2).
In these patients, no respiratory specimen cultures were obtained, and antibiotics had not been initiated or had been discontinued based on negative blood cultures by the time of research sampling. Notably, two of these individuals experienced sustained vasodilatory shock and died from multiorgan dysfunction attributed to isolated SARS-CoV-2 infection. 


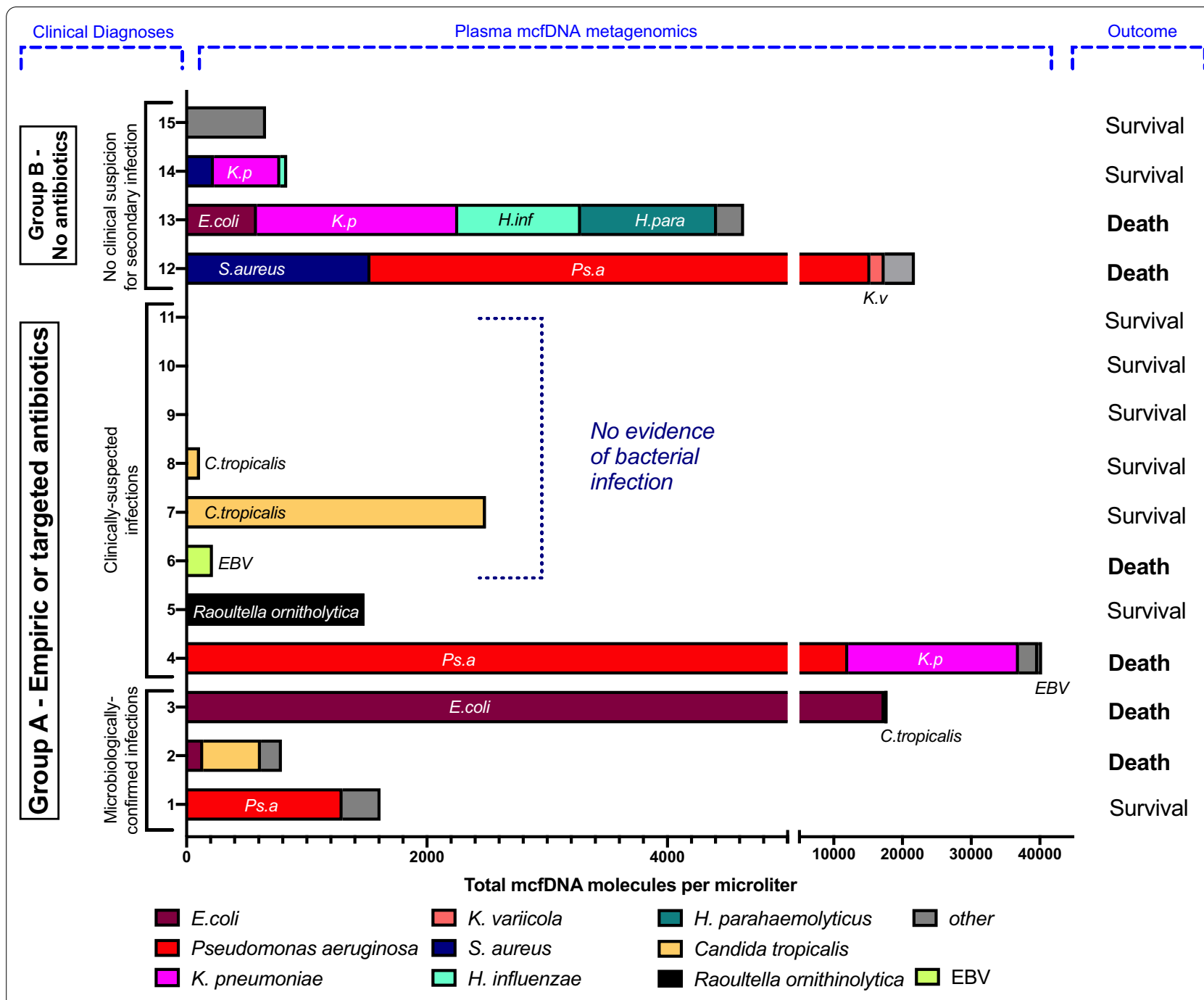

Fig. 2 Case-based analysis of 15 critically ill patients with COVID-19 with depicted clinical diagnoses, plasma microbial cell-free DNA metagenomics and survival outcomes. The Y-axis margin indicates two groups of clinical diagnoses: Group A includes 11 patients who received antibiotics for either microbiologically-confirmed $(n=3)$ or clinically-suspected infections despite negative microbiologic workup $(n=8)$, whereas Group B includes four patients with low clinical suspicion for secondary infection and no antibiotic therapies at time of sampling. The Y-axis ticks denote each patient sample and the $x$-height of each stacked bar represents the number of microbial cell-free DNA molecules per plasma microliter (MPMs) by metagenomic sequencing, with different colors for the top 10 microbes by ranked abundance. The "other" category (shown in grey) represents the sum of lower abundance taxa of commensal origin. Five out of 11 subjects of Group A (45\%, Subjects 1-5) had high MPM signal for probable respiratory pathogens, whereas in the remaining $6 / 11$ subjects there was no evidence of co-infecting bacterial pathogens. Subject 7 was clinically-diagnosed with culture-negative sepsis and treated with prolonged course of empiric broad-spectrum antibiotics while on extracorporeal membrane oxygenation support for refractory hypoxemic respiratory failure from COVID-19; the high mcfDNA signal for C.tropicalis (2,490 MPMs) is concerning for undiagnosed invasive Candidiasis, corroborated by persistent growth of yeast organisms (not further speciated) from clinical bronchoalveolar lavage samples obtained on days 5, 9 and 14 after the research sample acquisition. Two out of four patients of Group B (subjects 12 and 13) who did not survive and had not received empiric antimicrobials were found to have high mcfDNA signal (> 4000 total MPMs) of probable respiratory pathogens, indicative of undiagnosed (and untreated) secondary infections

\section{Discussion}

McfDNA-Seq in patients with COVID-19 indicates a higher incidence of probable secondary infections than previously recognized. Despite our small sample size, the significant association between mcfDNA and 30-day mortality suggests that COVID-19 severity may be influenced by circulating bacterial fragments, either from secondary pneumonias or from possible translocation of colonizing microbiota along the disrupted alveolar/epithelial surface of lungs injured by COVID-19 [5]. Integration of mcfDNA detection with clinical data demonstrates opportunity for antibiotic stewardship in 
patients with suspected infection. On the other hand, the signal for undiagnosed and untreated secondary infections should serve as a call for vigilance and thorough diagnostic workup in patients with severe COVID-19 [6].

\section{Acknowledgements}

We would like to thank the multiple investigators that contributed to our clinical research efforts for COVID-19, including investigators from the Acute Lung Injury Center of Excellence and the Center for Medicine and the Microbiome at the University of Pittsburgh, and the collaborators from Karius, Inc.

\section{Authors' contributions}

Conception and design: GDK, AM; Acquisition, analysis or interpretation of data: GDK, WB, NAY, RD, AAA, BJM, AM; Drafting of work and/or revising for important intellectual content: GDK, WB, NAY, RD, AAA, BJM, AM; Final approval of version to be published; agreement to be accountable for all aspects of the work in ensuring that questions related to the accuracy or integrity of any part of the work are appropriately investigated and resolved: GDK, WB, NAY, RD, AAA, BJM, AM. All authors read and approved the final manuscript.

\section{Funding}

This work was supported by Career Development Award Number IK2 BX004886 from the United States Department of Veterans Affairs Biomedical Laboratory R\&D (BLRD) Service (W.B.); the National Heart, Lung, And Blood Institute of the National Institutes of Health under Award Numbers K23 HL129987 (G.D.K); P01HL114453 (B.J.M.); University of Pittsburgh Clinical and Translational Science Institute COVID-19 Pilot Grant Program (G.D.K).

\section{Availability of data and materials}

All de-identified data are available from the authors upon request.

\section{Ethics approval and consent to participate}

This study was approved by the University of Pittsburgh Institutional Review Board (Protocol STUDY19050099). Written informed consent was provided by all participants or their surrogates in accordance with the Declaration of Helsinki.

\section{Competing interests}

Dr. Bryan J. McVerry has been a consultant for Vapotherm, Inc. and receives research funding from Bayer Pharmaceuticals, Inc. Dr. Georgios Kitsios has received research funding from Karius, Inc. The other authors have no conflicts of interest to declare.

\section{Author details}

${ }^{1}$ Division of Pulmonary, Allergy and Critical Care Medicine, Acute Lung Injury Center of Excellence, University of Pittsburgh Medical Center, UPMC Montefiore Hospital, NW 628, 3459 Fifth Avenue, Pittsburgh, PA 15213, USA.

${ }^{2}$ Veterans Affairs Pittsburgh Healthcare System, Pittsburgh, PA, USA. ${ }^{3}$ Department of Medicine, University of Pittsburgh Medical Center Mercy, Pittsburgh, PA, USA. ${ }^{4}$ Karius Inc, Redwood City, CA, USA.

Received: 5 November 2020 Accepted: 10 January 2021

Published online: 20 January 2021

\section{References}

1. Garcia-Vidal C, Sanjuan G, Moreno-García E, Puerta-Alcalde P, Garcia-Pouton N, Chumbita M, et al. Incidence of co-infections and superinfections in hospitalized patients with COVID-19: a retrospective cohort study. Clin Microbiol Infect. 2020. https://doi.org/10.1016/j.cmi.2020.07.041.

2. Wahidi MM, Shojaee S, Lamb CR, Ost D, Maldonado F, Eapen G, et al. The use of bronchoscopy during the coronavirus disease 2019 pandemic: CHEST/AABIP guideline and expert panel report. Chest. 2020;158:126881. https://doi.org/10.1016/j.chest.2020.04.036.

3. Kitsios GD, Yang H, Yang L, Qin S, Fitch A, Wang X-H, et al. Respiratory tract dysbiosis is associated with worse outcomes in mechanically-ventilated patients. Am J Respir Crit Care Med. 2020. https://doi.org/10.1164/ rccm.201912-24410C.

4. Blauwkamp TA, Thair S, Rosen MJ, Blair L, Lindner MS, Vilfan ID, et al. Analytical and clinical validation of a microbial cell-free DNA sequencing test for infectious disease. Nat Microbiol. 2019;4:663-74. https://doi. org/10.1038/s41564-018-0349-6.

5. Arunachalam PS, Wimmers F, Mok CKP, Perera RAPM, Scott M, Hagan T, et al. Systems biological assessment of immunity to mild versus severe COVID-19 infection in humans. Science. 2020;369:1210-20. https://doi. org/10.1126/science.abc6261.

6. Cox MJ, Loman N, Bogaert D, O'Grady J. Co-infections: potentially lethal and unexplored in COVID-19. Lancet Microbe. 2020;1:e11. https://doi. org/10.1016/S2666-5247(20)30009-4.

\section{Publisher's Note}

Springer Nature remains neutral with regard to jurisdictional claims in published maps and institutional affiliations.
Ready to submit your research? Choose BMC and benefit from:

- fast, convenient online submission

- thorough peer review by experienced researchers in your field

- rapid publication on acceptance

- support for research data, including large and complex data types

- gold Open Access which fosters wider collaboration and increased citations

- maximum visibility for your research: over $100 \mathrm{M}$ website views per year

At BMC, research is always in progress.

Learn more biomedcentral.com/submissions 